\title{
Regional water resources carrying capacity index system evaluation model and its application
}

\author{
Yingqin Chen \\ Department of Civil Engineering, Hohai University Wentian College, Ma'anshan, China \\ chenyingqin_nj@163.com
}

\begin{abstract}
Keywords: Water resources carrying capacity; Evaluation; Set pair analysis; Indicator system
\end{abstract}
Abstract. Water carrying capacity assessment is to reveal the relationship between water resources, population, and economy, fully use water resources, and make economic development go hand in hand with protection of water resources, which simultaneously promote sustainable social and economic development. Based on the analysis of water resources carrying capacity defined, according to the measure of the demand for sustainable use of water resources, the paper combines the principle of selecting evaluation, uses combination of quantitative and qualitative analysis method to prefer indicators, in order to meet the maximum importance, representativeness, certainty and independence of indicators, then establishes 20 evaluation index system from three aspects of socio-economic, ecological environment and water resources systems. Based on the existing research results, combine the social and economic development level and characteristics of water resources carrying capacity assessment, regional water resources carrying capacity is divided into five levels: good, better, normal, poorer and poor. Set pair analysis method is proposed to evaluate the system, which can be described some certainty and uncertainty, and fully reflect the unity of opposites certainty and uncertainty system. Compared with traditional evaluations such as expert scoring method, fuzzy comprehensive evaluation method, gray clustering evaluation method, principal component analysis and factor analysis method, set pair analysis method can objective reflect the real situation of the evaluation and is simple to calculate and more workable. Finally, Gaochun District, which located in the southwest of Jiangsu Province, China, is select as a case study area. Consider the future direction of social and economic development, certain engineering and non-engineering measures can significantly improve the local water resources carrying capacity.

\section{Introduction}

Because of uneven distribution of water resources, with the rapid development of the growing population and the social economy, water shortages and deteriorating water quality has become the "bottleneck" factor of constraint sustainable socio-economic development. Situation cannot carry their own social and economic development of water resources in many cities has occurred. Sustainable development of water resources carrying capacity is an important part in the variety of natural resources carrying capacity of a country or a region, is essential for comprehensive development of a country or region. To solve the problem of water shortages, to achieve sustainable social and economic development in the region, we must first in-depth analysis of the carrying capacity of local water resources, providing water resources to support decision-making basis for socio-economic development and regional planning.

The purpose of the evaluation of the water resources carrying capacity is to reveal the relationship between water resources and population, fully rational utilize water resources, make economic development and protection of water resources, then promote sustainable social and economic development. Although some scholars at home and abroad have been research water resources carrying capacity, made some research results, such as Harris (1999) studied the agricultural production regional water resources carrying capacity of agriculture, the result as a measure of regional development potential [1]. Munther (2000) study the perspective of urban water resources carrying capacity, and integrate it into urban development planning [2]. In our country, some scholars study the water resources carrying capacity [3]. Zhou Lin (2007) using principal component analysis 
study the water resources carrying capacity of Jiangmen City [4]. Yang Guang (2009) use Manes River Basin as a typical arid region, comprehensive value basin water resources carrying capacity through establish matter-element model [5]. Chang Jin (2013) proposed a projection pursuit classification model for water resources carrying capacity has been studied [6]. However, due to the complexity of the relationship between interconnected systems of water resources and the support of social and economic systems, water resources carrying capacity and sustainable development is not clear, analysis and evaluation of water resources carrying capacity is also mainly limited to static analysis, not reflect the characteristics and development of the target area. Set Pair Analysis is a new method of uncertainty analysis proposed by scholar Zhao Keqin [7], from the overall research and analysis on the intrinsic relationship between the local system, the method is clear concept, structure simple, calculation simple, easy to operate, has been widely used in the evaluation of water resources system [8,9]. In this paper, aim at the regional water resources carrying capacity, use set pair analysis method to evaluate water resources carrying capacity assessment provides a new approach.

\section{Regional water resources carrying capacity}

The concept of carrying capacity of water resources including natural and social respects, the composed system is very complex, large, including a number of factors, which influence and role each other, there is also active and reactive. Therefore, the definition of water resources carrying capacity, there is no unified understanding. Many scholars have put forward their points. Shi Yafeng recognize that water resources carrying capacity is the water resources in certain areas, in certain stages of social history and science and technology development, while not undermining social and ecological systems, the maximum load the capacity of agriculture, industry, city size and population, is a change integrated goal of social, economic, scientific and technological development [10]. Xu You-peng proposed water resources carrying capacity refers to certain technical and economic level and social production conditions, the ability of water resources supply agricultural production, people living and ecological environment protection, which is the largest water resources development capacity, in this capacity, water can be updated and natural circulation, continue to be utilized by people and benefit mankind, without causing environmental degradation [11]. Chen yangbo define water resources carrying capacity is "a certain area of water resources, to meet the conditions for the water resources sustainable use, can support the scale of social and economic - population - environmental development [12]"

\section{Regional water resources carrying capacity evaluation index system}

\section{Evaluation index system construction}

Yang Guang (2009) use water resources in arid areas and utilization characteristics establish water carrying capacity evaluation indicator system, such as the per capita amount of water resources, water resources utilization rate, vegetation coverage, sewage treatment rate, ecological environment water rate, natural population growth, urban rate, per capita GDP, proportion of tertiary industry in GDP, per capita share of grain, water-use efficiency and other 11 indicators [5]. Chen Nanxiang (2010) refer to the national indicator system of water supply and demand balance analysis, based on socio-economic development of Yuzhou and water utilization, ultimately select 8 indicators as water resources carrying capacity indicators evaluation index, such as the amount of water per capita, per capita water supply, water use efficiency, water demand modulus, fixed domestic water, industrial yuan output value of water, farmland irrigation rate, ecological environment water rate [13].

\section{Index system evaluation criteria}

Index system evaluation criteria are an important part of water resources carrying capacity evaluation, directly affect the objectivity and accuracy of the evaluation results. At present, index system evaluation criteria is few studied, such as Yang Guang (2009) gives three evaluation criteria for its 11 
indicators index system [5]. Chen Nanxiang (2010) for its 8 indicators divided into three evaluation levels [13].

Based on the existing research results, combine the social and economic development level and characteristics of water resources carrying capacity assessment, regional water resources carrying capacity is divided into five levels: good, better, normal, poorer and poor.

Considering the indicators average, the upper limit and lower limit values of China in recent years, as well as some related indicators alert the international community, according to five levels, identified 20 evaluation indicators of the evaluation criteria, such as GDP per capita and GDP growth rate, reference the analysis of economic development nearly 10 years and regional economic development level, comprehensive identified 5 evaluation criteria, urbanization rate based on the overall development plan of different cities determine evaluation criteria, per capita water resources, per capita water supply and water resources utilization are analyzed according to various regions of our country as well as water resources development and utilization of water supply, identify 5 evaluation criteria. Other index system is a comprehensive analysis to determine the socio-economic development in accordance with relevant information and research results has a certain reference value.

Water resources carrying capacity evaluation index criteria are in Table 1.

Table 1. Water resources carrying capacity evaluation index criteria

\begin{tabular}{|c|c|c|c|c|c|}
\hline Evaluation index & Poor & Poorer & Normal & better & Good \\
\hline Per capita GDP (million) & $<1.0$ & $1.0-1.5$ & $1.5-2.0$ & $2.0-2.5$ & $>2.5$ \\
\hline GDP growth $(\%)$ & $<8.5$ & $8.5-9.0$ & $9.0-9.5$ & $9.5-10.0$ & $>10.0$ \\
\hline $\begin{array}{l}\text { Comprehensive yuan GDP } \\
\text { water consumption }\left(\mathrm{m}^{3}\right)\end{array}$ & $>600$ & $300-600$ & $100-300$ & $50-100$ & $<50$ \\
\hline $\begin{array}{l}\text { Industrial output proportion } \\
\text { of GDP (\%) }\end{array}$ & $<30$ & $30-40$ & $40-50$ & $50-60$ & $>60$ \\
\hline $\begin{array}{l}\text { Population density (people } \\
\qquad / \mathrm{km}^{2} \text { ) }\end{array}$ & $>800$ & $700-800$ & $600-700$ & $500-600$ & $<500$ \\
\hline $\begin{array}{l}\text { Natural population growth } \\
\text { rate }(\%)\end{array}$ & $>7$ & $5-7$ & $3-5$ & $1-3$ & $<1$ \\
\hline Urbanization rate $(\%)$ & $<35$ & $35-40$ & $40-45$ & $45-50$ & $>50$ \\
\hline $\begin{array}{l}\text { Water demand modulus } \\
\text { (ten thousand } \mathrm{m}^{3} / \mathrm{km}^{2} \text { ) }\end{array}$ & $>80$ & $60-80$ & $45-60$ & $30-45$ & $<30$ \\
\hline $\begin{array}{l}\text { Eco-environmental water } \\
\text { rates }(\%)\end{array}$ & $<2$ & $2-3$ & $3-4$ & $4-5$ & $>5$ \\
\hline Forest coverage $(\%)$ & $<9$ & $9-12$ & $12-15$ & $15-18$ & $>18$ \\
\hline Soil erosion rate (\%) & $>25$ & $20-25$ & $15-20$ & $12-15$ & $<12$ \\
\hline $\begin{array}{l}\text { River and lake water rates } \\
(\%)\end{array}$ & $<6$ & $6-9$ & $9-12$ & $12-15$ & $>15$ \\
\hline $\begin{array}{l}\text { Water Environmental } \\
\text { Capacity }\end{array}$ & $\begin{array}{c}\text { Assimilative } \\
\text { capacity is far less } \\
\text { than the amount } \\
\text { of pollutants }\end{array}$ & $\begin{array}{l}\text { Assimilative } \\
\text { capacity of slightly } \\
\text { less than the } \\
\text { amount of } \\
\text { pollutants }\end{array}$ & $\begin{array}{l}\text { Assimilative } \\
\text { capacity is equal to } \\
\text { the amount of } \\
\text { pollutants }\end{array}$ & $\begin{array}{c}\text { Assimilative capacity } \\
\text { is slightly larger than } \\
\text { the amount of } \\
\text { pollutants }\end{array}$ & $\begin{array}{l}\text { Assimilative capacity } \\
\text { is much larger than the } \\
\text { amount of pollutants }\end{array}$ \\
\hline Surface water quality & $\begin{array}{l}\text { Compliance rate } \\
\text { of water } \\
\text { functional areas } \\
<60 \%\end{array}$ & $\begin{array}{l}\text { Compliance rate of } \\
\text { water functional } \\
\text { areas } 60 \%-70 \%\end{array}$ & $\begin{array}{l}\text { Compliance rate of } \\
\text { water functional } \\
\text { areas } 70 \%-80 \%\end{array}$ & $\begin{array}{c}\text { Compliance rate of } \\
\text { water functional areas } \\
80 \%-90 \%\end{array}$ & $\begin{array}{c}\text { Compliance rate of } \\
\text { water functional } \\
\text { areas }>90 \%\end{array}$ \\
\hline Ground water quality & $\mathrm{V}$ & IV & III & II & I \\
\hline Sewage treatment rate $(\%)$ & $<35$ & $35-50$ & $50-65$ & $65-80$ & $>80$ \\
\hline $\begin{array}{l}\text { Per capita water resources } \\
\qquad\left(\mathrm{m}^{3} / \text { people }\right)\end{array}$ & $<1700$ & $1700-2200$ & $2200-2500$ & $2500-3000$ & $>3000$ \\
\hline $\begin{array}{l}\text { Per capita water supply } \\
\left(\mathrm{m}^{3} / \text { people }\right)\end{array}$ & $<250$ & $250-300$ & $300-350$ & $350-400$ & $>400$ \\
\hline $\begin{array}{l}\text { Utilization of water } \\
\text { resources }(\%)\end{array}$ & $>80$ & $65-80$ & $45-65$ & $30-45$ & $<30$ \\
\hline $\begin{array}{l}\text { Water modulus }(\text { ten } \\
\left.\text { thousand } \mathrm{m}^{3} / \mathrm{km}^{2}\right)\end{array}$ & $>80$ & $60-80$ & $45-60$ & $30-45$ & $<30$ \\
\hline
\end{tabular}




\section{Set pair analysis assessment model}

\section{Principles of set pair analysis evaluation model}

Set pair analysis is a systematic analysis of handling the uncertainty problem, the core idea is contact objective things and uncertainties of being studied deterministic as a system analysis and processing. So-called set means two sets which have some contact pairs consist, principle of set means in a certain context, analysis the identity, difference, opposition of two pair sets (A, B) features. Uncertainty relation of set described by contact degree, which is

$$
\mu_{A-B}=\frac{S}{N}+\frac{F}{N} i+\frac{P}{N} j
$$

Where: $\mathrm{N}$ is the total number of the sets; $\mathrm{S}$ is the number of identical; $\mathrm{P}$ is the number of oppositional; $\mathrm{F}$ is the number of differences; $i$ is uncertainty factor, depending on difference circumstances take the value of the range $(1,1)$, sometimes only play the role of differentially labeled; $j$ is opposed coefficients, in the calculation, sometimes only play the role of marked antagonistic. Usually make $\mathrm{a}=\mathrm{S} / \mathrm{N}$, known as same degree, $\mathrm{b}=\mathrm{F} / \mathrm{N}$ is called difference degree, $\mathrm{c}=\mathrm{P} / \mathrm{N}$ is called opposition degree. By the definition, $a, b$, c satisfy the normalization condition $a+b+c=1$, so the formula (1) can be written as

$$
\mu_{A-B}=a+b i+c j
$$

Formula (1) and (2) is commonly used several contact. Usually take $b i$ of $\mu_{A-B}=a+b i+c j$ expands to $b i=b_{1} i_{1}+b_{2} i_{2}+\ldots+b_{k} i_{k}$, then obtain the hierarchy mathematical formula, such as $\mathrm{k}=3$, can get a five-membered contact degree expressions.

$$
\mu_{A-B}=a+b_{1} i_{1}+b_{2} i_{2}+b_{3} i_{3}+c j
$$

Where: $a, b_{1}, b_{2}, b_{3}, c$ called the contact component, which meet the normalization condition; $i_{1}, i_{2}, i_{3}, j$ called the contact component coefficient, $i_{1}, i_{2}, i_{3}$ the real difference is the component form of uncertainty factor $i$. Value $i_{1}, i_{2}, i_{3}, j$, get the value of contact degree called five-membered contact number.

For a specific question, when the set is composed, contact components can be directly calculated, usually take $j=-1$, so the central question is to determine $i_{1}, i_{2}$ and $i_{3}$. When they determined, the value of the contact degree of the problem is determined.

\section{Method of contact component coefficients'value}

When data and standard are given, the contact component $a, b_{1}, b_{2}, b_{3}, c$ in SPA is a certain problem, while the contact component coefficient $i_{1}, i_{2}, i_{3}$ is uncertain. In this paper, select the coefficient of contact component $a$ is 1 in formula (3), that compare with the assessment and classification criteria index is in five contact component; $b_{1}$ means the comparison of the sample value comparison and evaluation classification criteria, is in four linked components, its coefficient $i_{1}, i_{2}, b_{2}$ and $b_{3}, i_{3}$ and so on.

\section{Case studies}

Gaochun District located in the southwest of Jiangsu Province, locate at latitude $31^{\circ} 13^{\prime} \sim 31^{\circ} 26^{\prime}$, longitude $118^{\circ} 41^{\prime} \sim 119^{\circ} 12^{\prime}$, Lishui is in the north, Liyang is in the east, southern and western Anhui langxi, XuanZhou, Dangtu three counties (cities), have 8 town, 1 district and 163 administrative villages. North-south distance is $29 \mathrm{~km}$, the biggest distance of East-west apart $49 \mathrm{~km}$, with a total area $801.8 \mathrm{~km}^{2}$, which land area $566.5 \mathrm{~km}^{2}$, accounting for $70.65 \%$, water area $235.3 \mathrm{~km}^{2}$, 
accounting for $29.35 \%$. Gaochun area bounded by the gate of Maodong, belonging to Shuiyang River and Taihu two river systems. Territory west Shuiyang River wear through, in the middle Xu River, Guanxi River east to west, north and south communicate paint Bridge River, combined with Yunliang River, Hengxi River, Gangkou River, Shishu River, Zhuanqiang River, Shigu River, Yaxi River, totally 17 key rivers. And have 192 general rivers, 16 reservoirs, 21423 embankments. Gaochun district by district water resources can be divided into four, namely Guheng Lake West, Longdun River Reservoir, Gucheng Lake East and Taihu Lake West.

According to the basic situation of water resources Gaochun area, select 2012 as a representative year, calculate the corresponding evaluation. Taking into account Gaochun area belongs southern region, soil erosion is not obvious, so do not consider soil erosion rate index in actual evaluation. The indicators are shown in Table 2:

Table 2. Value of water evaluation index, Gaochun district, Nanjing

\begin{tabular}{|c|c|c|c|c|c|}
\hline Index & Index value & Index & $\begin{array}{l}\text { Index } \\
\text { value }\end{array}$ & Index & Index value \\
\hline $\begin{array}{l}\text { Per capita GDP (ten thousand } \\
\text { yuan / people) }\end{array}$ & 4.03 & $\begin{array}{l}\text { Water demand modulus (ten } \\
\text { thousand } \mathrm{m}^{3} / \mathrm{km}^{2} \text { ) }\end{array}$ & 98.12 & Sewage treatment rate $(\%)$ & 53 \\
\hline GDP growth $(\%)$ & 13 & $\begin{array}{c}\text { Eco-environmental water } \\
\text { rates }(\%)\end{array}$ & 8.25 & $\begin{array}{l}\text { Per capita water resources } \\
\left(\mathrm{m}^{3} / \text { people }\right)\end{array}$ & 6245.94 \\
\hline $\begin{array}{l}\text { Ten thousand yuan integrated } \\
\text { Water consumption }\left(\mathrm{m}^{3}\right)\end{array}$ & 200 & Forest coverage rate $(\%)$ & 26 & $\begin{array}{c}\text { Per capita water supply }\left(\mathrm{m}^{3} /\right. \\
\text { people })\end{array}$ & 1021.71 \\
\hline $\begin{array}{l}\text { Industrial output proportion of } \\
\text { GDP }(\%)\end{array}$ & 55 & $\begin{array}{l}\text { River and lake water rates } \\
\qquad(\%)\end{array}$ & 29.35 & $\begin{array}{l}\text { Utilization of water resources } \\
\qquad(\%)\end{array}$ & 45.4 \\
\hline Population density (people $/ \mathrm{km}^{2}$ ) & 531 & $\begin{array}{l}\text { Water environmental } \\
\text { capacity }\end{array}$ & Normal & $\begin{array}{l}\text { Water modulus (ten thousand } \\
\left.\qquad \mathrm{m}^{3} / \mathrm{km}^{2}\right)\end{array}$ & 76.76 \\
\hline $\begin{array}{l}\text { Natural population growth rate } \\
\qquad(\%)\end{array}$ & 2.48 & Surface water quality & Normal & & \\
\hline Urbanization rate $(\%)$ & 69 & Ground water quality & Normal & & \\
\hline
\end{tabular}

Set provided evaluation $\mathrm{C}=\{\mathrm{C} 1, \mathrm{C} 2, \mathrm{C} 3, \mathrm{C} 4, \mathrm{C} 5\}$, where $\mathrm{C} 1=\{1 /$ Fine $\}, \mathrm{C} 2=\{2 / \mathrm{Good}\}, \mathrm{C} 3=$ $\{3 /$ Normal $\}, \mathrm{C} 4=\{4 /$ Poor $\}, \mathrm{C} 5=\{5 / \mathrm{Bad}\}$.

Determine the relative weight of the heavy layers index system, the right weight of social economic systems, environmental systems and water systems are $(0.5472,0.1897,0.2631)$. Using the steps of set pair analysis, calculate level index comprehensive evaluation of five element connection number as shown in Table 3:

Table 3. Level index comprehensive evaluation of five-membered contact number, contact master number and rating scale principal value

\begin{tabular}{cccc}
\hline Number & One index & Comprehensive evaluation five-membered contact number & $\begin{array}{c}\text { Contact master } \\
\text { value }\end{array}$ \\
\hline 1 & $\begin{array}{c}\text { Socio-economic } \\
\text { system } \\
\text { Ecological } \\
2\end{array}$ & $\mu_{1}=0.4677+0.2912 i_{1}+0.0936 i_{2}+0.1475 j$ & $\mu_{1}=0.4658$ \\
3 & environment system & $\mu_{2}=0.3374+0.2375 i_{1}+0.3433 i_{2}+0.0818 j$ & $\mu_{2}=0.3743$ \\
\hline
\end{tabular}

Calculate and determine the five-element connection number of the total index comprehensive evaluation:

$$
\mu=0.5214+0.2357 i_{1}+0.1318 i_{2}+0.0148 i_{2}+0.0962 \mathrm{j}
$$

According to "sharing principle", five-element connection number value should be located in the interval $[-1,1]$ in four equal points, so make $i_{1}=0.5, i_{2}=0, i_{3}=-0.5, j=-1$ to get each one main evaluation index value $I_{m}(1 \leq \mathrm{m} \leq 3)$, which comprehensive assessment contact number of master values (see Table 3 ) and the total index, $\mu=0.5356$.

According to "sharing principle", determine the scope of the five-element connection number to five principal value of the interval $[0.6,1],[0.2,0.6],[-0.2,0.2],[-0.6,-0.2],[-1,-0.6]$, respectively 
response $\mathrm{C} 1=\{1 /$ Fine $\}, \mathrm{C} 2=\{2 /$ Good $\}, \mathrm{C} 3=\{3 /$ Normal $\}, \mathrm{C} 4=\{4 /$ Poor $\}, \mathrm{C} 5=\{5 /$ Bad $\}$ levels, can be seen Gaochun water resources carrying capacity is $2 /$ good.

\section{Proposals and measures}

Gaochun water resources development and utilization rate is not high, although the transit of water is very rich, but due to limitations of water supply capacity cannot meet the demand of water resources to provide social and economic development. In addition to the status quo in wet years, the water supply capacity and cannot meet the needs of the county's water, water carrying capacity potential uneven distribution, Gucheng Lake Western water resources carrying potential capacity is much higher than the other three partitions. With the social and economic development and people's living standards improve, increasing demand for water in industrial and agricultural production and daily life, the need to increase water conservation efforts to mitigate the potential carrying capacity of water resources decline. Gaochun in terms of workers and peasants and other industrial and ecological water allocation is not reasonable, affecting the water carrying capacity.

\section{Acknowledgements}

This work was financially supported by the University Natural Science Research Project in Anhui Province (KJ2017A898) and 2018 Academic Support Program for Academic Topics in Colleges and Universities in Anhui Province (gxbjZD62).

\section{References}

[1] Harris J N. Carrying capacity in agriculture: globe and issue [J]. Ecological Economics, vol 129(1999), p. 443-461.

[2] Munther J. H. Water issue in Hashemite Jorden [J]. Arab Study Quarterly. vol 22(2000), p.54-67.

[3] Yuan Y, Gan H, Wang Z. Discussion on progress and development trend of the research on water resources carrying capacity [J]. Journal of China Institute of Water Resources and Hydropower Research. vol 4(2006), p. 63-66.

[4] Zhou L, Jin H. Application of principal components method in the research of water resources carrying capacity of Jiangmen city [J]. Pearl River, vol 5(2007), p. 39-42.

[5] Yang G, He X, Li J. Water resources evaluation of dry region based on matter-element model [J]. Yangtze River, vol 40(2009), p. 52-54.

[6] Chang J, Zhao X. Application of PPC model in the evaluation of water resources carrying capacity [J]. Yellow River, vol 35(2013), p. 71-73.

[7] Zhao K. Set pair analysis and its preliminary application [M]. Hangzhou: Zhejiang science \& technology press (2000).

[8] Meng X, Hu H. Application of set pair analysis model based on entropy weight to comprehensive evaluation of water quality [J]. Journal of Hydraulic Engineering, vol 40(2009), p. 257-262.

[9] Zhao X, Hu C, Wang Y. A set pair analysis for evaluating on cmperhensive reservoir project schemes [J]. Water Power, vol 35(2009), p. 11-13.

[10] Shi Y, Qu Y. Water resources carrying capacity and the reasonable utilization in Urumqi River [M]. Beijing: Science Press(1992).

[11] Xu Y. Water resource carrying capacity in arid area [J]. Journal of natural resources, vol 8(1993), p. 229-237.

[12] Chen Y, Chen J. Issues in water carrying capacity study [J]. Acta Scientiarum Naturalium Universitatis Sunyatseni, vol 43(2004), p.181-185.

[13] Chen N, Chen K. Research based on matter element analysis method of water resources carrying capacity evaluation method [J]. Yellow River, vol 32(2010), p. 71-75. 